\title{
Kick Off Peningkatan Potensi Ekonomi Kreatif Masyarakat Melalui Koperasi, Bumdes dan UKM Berbasis Kearifan Lokal di Kabupaten Soppeng
}

\author{
M. Ardiansyah Syam ${ }^{1}$, Syahril Djaddang ${ }^{2}$, Fachrudin Salim ${ }^{3}$, Widiarto Rachbini ${ }^{4}$ \\ ${ }^{1,2,3,4}$ Sekolah Pascasarjana Universitas Pancasila, Jakarta Selatan, DKI Jakarta, Indonesia \\ E-mail: ardiansyah.2013.16@gmail.com
}

\begin{abstract}
Abstrak
Ekonomi Kreatif merupakan salah satu sektor yang diharapkan mampu menjadi kekuatan baru ekonomi nasional yang berkelanjutan, dan menekankan pada penambahan nilai barang melalui daya pikir serta kreatifitas manusia. Pada tahun 2019, ekonomi kreatif Indonesia tumbuh sebesar $6.25 \%$ melampai pertumbuhan ekonomi nasional. Untuk menumbuhkan dan meningkatkan potensi ekonomi kreatif berbasis kearifan lokal, pelatihan dasar kewirausahaan dan dasar-dasar akuntansi bagi pengurus dan anggota koperasi, bumdes dan UKM merupakan hal yang sangat diperlukan. Salah satu permasalahan yang dihadapi oleh Usaha kecil dan Menengah (UKM) adalah akses permodalan baik dari bank maupun lembaga keuangan lainnya yang disebabkan oleh ketidakmampuan pemilik Usaha Kecil dan Menengah untuk menyajikan laporan keuangan usahanya dengan benar. Tujuan dari pelatihan dasar kewirausahaan dan dasar-dasar akuntasi ini adalah untuk menginisiasi anggota masyarakat untuk menjadi wirausahawan yang memahami pentingnya pencatatan dan pelaporan keuangan berdasarkan disiplin akuntansi. Berdasarkan data dari Badan Ekonomi Kreatif Indonesia, Sulawesi Selatan memiliki 188.547 unit ekonomi kreatif, dan 181.048 atau $96.02 \%$ belum memiliki badan usaha. Di Kabupaten Soppeng tercatat hanya $1.2 \%$ pelaku usaha ekonomi kreatif. Untuk itu pelatihan dasar kewirausahaan dan dasardasar akuntansi merupakan salah satu solusi awal untuk menginisiasi dan membina pelaku ekonomi kreatif. Sebagai rekomendasi, pelatihan mengenai pentingnya badan usaha dari aspek hukum dan legalitas perlu dilakukan sebagai tindak lanjut dari pelatihan dasar kewirausahaan dan dasar-dasar akuntansi.
\end{abstract}

Kata Kunci: Ekonomi kreatif, kearifan lokal, pelatihan dasar kewirausahaan, pelatihan dasar-dasar akuntansi.

\begin{abstract}
The Creative Economy is one of the sectors that is expected to be a new strength of the national economy that is sustainable, and emphasizes the addition of value through the power of thought and human creativity. In 2019, Indonesia's creative economy grow by $6.25 \%$ beyond national economic growth. To foster and enhance the potential of the creative economy based on local wisdom, entrepreneurship basic training and accounting basics for management and members of cooperatives, community service and SMEs is very necessary. One of the problems faced by Small and Medium Enterprises (SMEs) is access to capital from both banks and other financial institutions caused by the inability of Small and Medium Business owners to present their business financial statements correctly. The aim of this basic entrepreneurship training and the fundamentals of accounting is to initiate community members to become entrepreneurs who understand the importance of financial recording and reporting based on accounting discipline. Based on data from the Indonesian Creative Economy Agency, South Sulawesi has 188,547 creative economy units, and 181,048 or 96.02\% do not have business entities. In Soppeng Regency, there are only 1.2\% of creative
\end{abstract}


economy entrepreneurs. To that end, basic entrepreneurship training and fundamentals of accounting is one of the initial solutions for initiating and fostering creative economic actors. As a recommendation, training on the importance of business entities from legal and legal aspects needs to be done as a follow-up to basic entrepreneurship training and fundamentals of accounting.

Send feedback

Keywords: Creative economics, local genuine, basics entrepreneurship training, basics accounting training.

\section{PENDAHULUAN}

Ekonomi Kreatif berhubungan dengan ide dan uang. Ini adalah jenis ekonomi pertama di mana imajinasi dan kreativitas menentukan apa yang orang- orang ingin lakukan dan hasilkan (Howkins, 2013). Ekonomi Kreatif (Ekraf) merupakan salah satu sektor yang diharapkan mampu menjadi kekuatan baru ekonomi nasional yang berkelanjutan, dan menekankan pada penambahan nilai barang lewat daya pikir serta kreatifitas manusia. Saat ini, Ekonomi kreatif menjadi katalisator bagi pertumbuhan ekonomi Indonesia ditengah perlambatan pertumbuhan ekonomi global. Pemerintah Indonesia dalam hal ini Badan Ekonomi Kreatif (Bekraf) menaruh perhatian lebih terhadap sektor ini, dengan tujuan untuk memaksimalkan potensi dan peluang Ekonomi Kreatif di Indonesia.

Prospek perekonomian Indonesia yang akan menjadi salah satu negara dengan pendapatan tertinggi di dunia pada 2030, Ekonomi Kreatif di Indonesia turut ditargetkan akan menjadi salah satu kekuatan industri kreatif dunia. Harapan Ekonomi Kreatif Indonesia untuk menjadi kekuatan baru ekonomi nasional di masa mendatang mulai menunjukkan gambaran positif mengingat kontribusi PDB (Produk Domestik Bruto) Ekonomi Kreatif terhadap PDB nasional terus menunjukkan peningkatan setiap tahunnya.Melalui Badan Ekonomi Kreatif (BEKRAF), Pemerintah Indonesia berusaha memberikan inovasi serta menaruh perhatian lebih terhadap sektor ini, dengan tujuan untuk menggali potensi dan memaksimalkan peluang sekaligus mengatasi tantangan Ekonomi Kreatif yang ada di Indonesia.

Salah satu aspek penting dalam pengembangan Ekonomi Kreatif adalah ketersediaan data dan informasi statistik yang menjadi dasar dalam pengambilan kebijakan serta keputusan, baik bagi pemerintah maupun pelaku Ekonomi Kreatif. Dalam rangka pemenuhan kebutuhan data tersebut, Badan Ekonomi Kreatif kembali bekerjasama dengan Badan Pusat Statistik (BPS) pada tahun 2017 lalu dalam melakukan penyusunan database statistik Ekonomi Kreatif yang memuat informasi seputar data indikator Makro dan analisis hasil Sensus Ekonomi 2016 (SE 2016). Data ekonomi kreatif Provinsi Sulawesi Selatan per Kabupaten/Kota dapat dilihat pada Gambar 1 di bawah ini: 


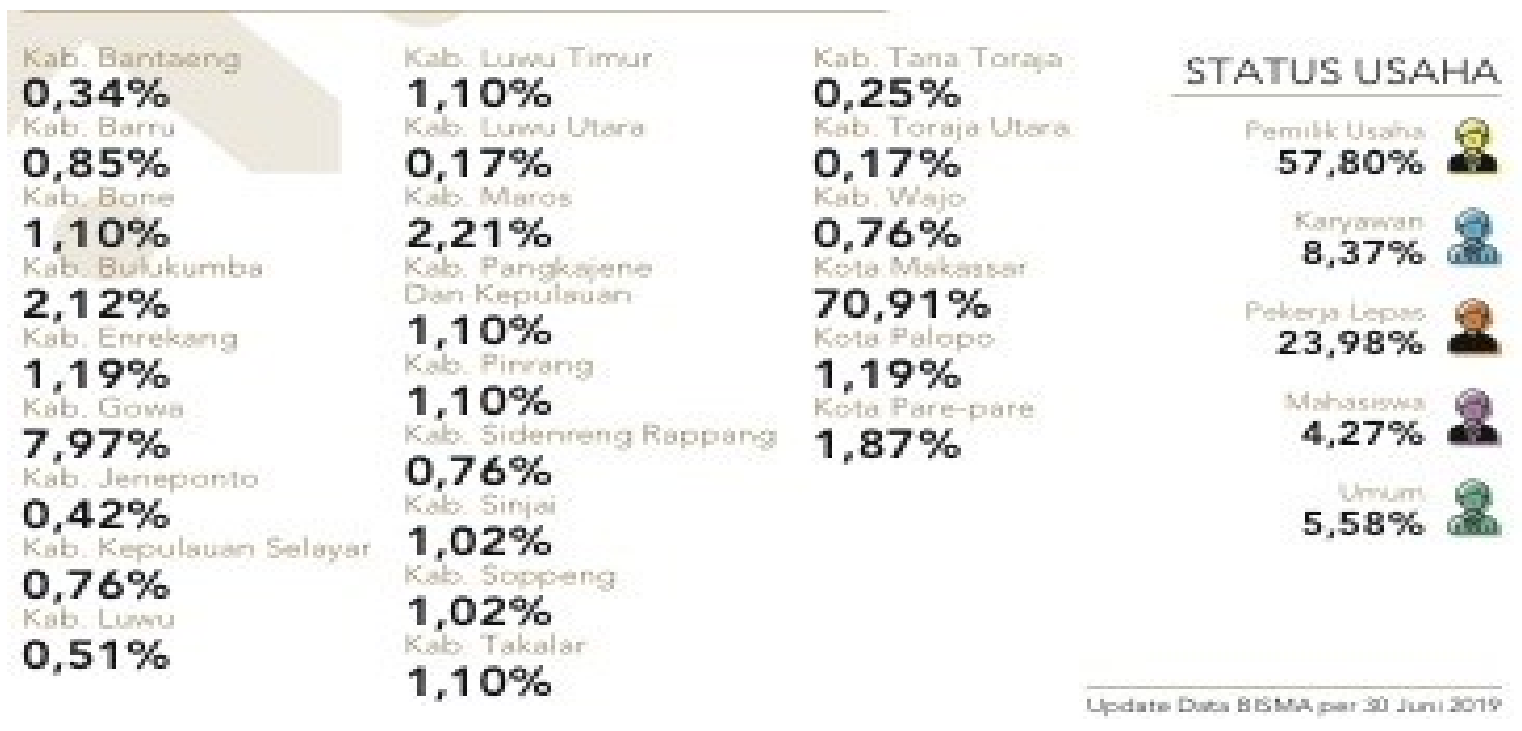

Sumber: Badan Ekonomi Kreatif Indonesia (2019, p 63)

Gambar 1: Ekonomi Kratif Sulawesi Selatan Per Kabupaten/Kota

Adapun masalah utama yang dihadapi oleh pelaku ekonomi kreatif yang sebagian besar koperasi dan UMKM adalah akses permodalan ke perbankan maupun lembaga non-perbankan lainnya (Abeng, 2015). Penyebabnya adalah ketidakmampuan pelaku usaha ekonomi kreatif dalam melakukan pencatatan dan menyajikan laporan keuangan secara baik dan benar berdasarkan prinsip akuntansi yang berlaku umum. Untuk itu pelatihan di bidang kewirausahaan dan dasar-dasar akuntansi perlu untuk dilakukan guna menginisiasi dan mendorong pertumbuhan kegiatan ekonomi kreatif berbasis kearifan lokal sehingga memiliki competitive advantage baik ditingkat nasional maupun global. Satari \& As'ad (2018), dalam penelitiannya menyimpulkan bahwa perlu dukungan dari semua stakeholder (pelaku ekonomi kreatif, institusi pendidikan, pemerintah daerah dan pemerintah pusat) untuk menciptakan ecosystem ekonomi kreatif di Indonesia. Institusi pendidikan dapat mengambil peran untuk memberikan pelatihan di bidang kewirausahaan dan dasar-dasar akuntansi dan proses bisnis lainnya guna menumbuhkan ekonomi kreatif di Indonesia berbasis kearifan lokal.

Tujuan penelitian tindakan (action research) ini adalah untuk mendeskripsikan, menginterpretasi dan mengidentifikasikan Kick of peningkatan potensi ekonomi kreatif masyarakat melalui Koperasi, Bumdes dan UKM berbasis kearifan lokal di Kabupaten Soppeng.

\section{METODE PELAKSANAAN}

Metode pelaksanaan diuraikan dengan analisis situasi pengabdian kepada masyarakat ini mengunakan metode penelitian tindakan (action research). Penelitian tindakan merupakan salah satu bentuk rancangan penelitian, dalam penelitian tindakan peneliti mendeskripsikan, 
menginterpretasi dan menjelaskan suatu situasi sosial pada waktu yang bersamaan dengan melakukan perubahan atau intervensi dengan tujuan perbaikan atau partisipasi rekruitment dan pendampingan Koperasi, BUMDES, Industri kreatif dan UMKM dan pelatihan penyajian hasil usaha berdasarkan PSAK ETAP (Pernyataan Standar Akuntansi Keuangan - Entitas Tanpa Akuntabilitas Publik) Koperasi dan PSAK ETAP UMKM yang mencakup langkah-langkah pelaksanaan pengabdian kepada masyarakat berikut ini;

a. Pola rekrutmen tenant (Koperasi, BUMDES dan Wirausaha kreatif) peserta pengabdian, mengacu kepada luaran program, sepuluh (10) wirausaha baru/tahun/wilayah/Desa. Adapun pola rekruitmen semua wirausaha kreatif sebagai tenant (Koperasi dan Bumdes) peserta perdesa di Kabupaten Soppeng.

b. Metode pendekatan action research dan FGD yang akan diterapkan seperti pelatihan perkoperasian, kewirausahaan kreatif, pencatatan dan pembukuan sesuai dengan PSAK ETAP Koperasi dan PSAK ETAP UMKM, pola pembimbingan, pengawasan terhadap tenant, teknik pembiayaan usaha tenant (Koperasi dan BUMDES), pola pemberian bantuan teknologi dan metode penyelesaian masalah dengan metode pencatatan berbasis PSAK ETAP (Pernyataan Standar Akuntansi Keuangan - Entitas Tanpa Akuntabilitas Publik) Koperasi dan PSAK ETAP UMKM berbasis kearifan lokal .

c. Kemungkinan adanya kolaborasi dengan lembaga PEMKAB, Koperasi dan BUMDES dan pola operasinya. Kolaborasi dengan lembaga yang terkait dalam hal pelatihan metode pencatatan berbasis PSAK ETAP (Pernyataan Standar Akuntansi Keuangan Entitas Tanpa Akuntabilitas Publik) Koperasi dan PSAK ETAP UMKM.

d. Penjelasan secara rinci mengenai persiapan, pelaksanaan, dan evaluasi kegiatan pengabdian yang mengacu kepada uraian dalam metode pelaksanaan. Persiapan pembinaan koperasi, BUMDES dan UMKM dilakukan secara periodik sebulan sekali dengan pola pelatihan rekrutment tenant peserta wirausaha kreatif per desa dan pola evaluasi dilakukan secara bertahap dan sinergi dengan praktisi koperasi, dosen dan wirausaha kreatif di Kabupaten Soppeng.

e. Hasil binaan koperasi, BUMDES dan UMKM kreatif secara wajar yang menjadi wirausaha kreatif per tahun dan strategi peningkatan usaha kembali sehingga terwujud 
koperasi Desa mandiri dan BUMDES mandiri. Jumlah koperasi dan BUMDES per tahun/Desa selama tiga tahun dinyatakan secara wajar saat pelatihan metode pencatatan PSAK ETAP (Pernyataan Standar Akuntansi Keuangan - Entitas Tanpa Akuntabilitas Publik) Koperasi dan UMKM, BUMDES pada semua wirausaha kreatif di Kabupaten Soppeng.

f. Rencana pengembangan pengabdian pada masyarakat pada tahun-tahun selanjutnya, dengan Pengembangan unit usaha kreatif dapat dikoordinir lansung oleh Tim Pengabdian pada Masyarakat kerjasama dengan PEMKAB dalam hal ini BUMDES untuk menerapkan PSAK ETAP (Pernyataan Standar Akuntansi Keuangan - Entitas Tanpa Akuntabilitas Publik) Koperasi dan PSAK ETAP UMKM dan wirausaha kreatif di Kabupaten Soppeng.

\section{PEMBAHASAN}

Pengembangan kewirausahaan di Indonesia didasarkan pada karakteristik daerah dengan tetap memperhatikan nilai-nilai sosial dan budaya yang berkembang di masyarakat berbasis kearifan lokal. Pengembangan kewirausahaan dilaksanakan sesuai minat, bakat, potensi masyarakat, potensi daerah dan arah pembangunan nasional. Artinya, pengembangan kewirausahaan bukanlah program yang disusun secara general untuk semua masyarakat, namun harus merupakan program spesifik yang sesuai dengan karakteristik setiap masyarakat di daerah. Setiap daerah memang memiliki nilai, sikap dan mental yang secara umum memiliki kesamaan, namun apabila dikaitkan dengan minat dan bakat serta potensi yang ada tentu saja sangat berbeda antara daerah yang satu dengan daerah yang lain. Hal ini menuntut program pengembangan kewirausahaan harus spesifik dan disesuaikan dengan minat, bakat dan potensi yang ada berbasis kearifan lokal.

Secara umum pengembangan kewirausahaan mencakup tahapan-tahapan sebagai berikut:

1. Tahap Akan Memulai Usaha (Pre start-up stage)

Tahapan ini merupakan tahapan awal dalam pengembangan kewirausahaan dengan melakukan program penyadaran akan pentingnya kewirausahaan pemuda. Tahapan awal ini juga merupakan tahapan untuk memberikan motivasi untuk membentuk sikap dan mental serta semangat untuk berwirausaha, menggali ide-ide dan minat untuk berusaha yang sesuai dengan bakat dan potensi yang dimiliki, dan mulai merumuskan perencanaan usaha yang akan dikembangkan berdasarkan ide-ide yang sudah muncul. Perencanaan usaha yang dirumuskan mulai dari menentukan jenis usaha, menentukan lokasi usaha, 
mengusahakan modal awal, menyusun kebutuhan investasi, membuat rencana kerja, dan pasarnya.

2. Tahap Memulai Usaha (The start-up stage)

Tahapan ini adalah tahapan dimana rencana usaha yang sudah dirumuskan sebelumnya mulai dijalankan. Pada tahapan ini sudah mulai dilakukan proses produksi dengan mulai belanja bahan produksi, proses produksi, dan memasarkan hasil produksi. Pada tahapan ini juga sudah mulai dikelola cash flow dan laporan keuangan lainnya. Pada tahap usaha mulai dijalankan ini, wirausahawan memerlukan pendampingan dan pembimbingan untuk menjalankan usahanya. Pendampingan dan pembimbingan yang perlu dilakukan khususnya dalam menyelesaikan pelbagai permasalahan yang muncul ketika usaha baru dimulai. Pelatihan-pelatihan ketrampilan yang terkait dengan produksi dan pengetahuan manajemen usaha juga perlu dilaksanakan pada tahapan ini.

3. Tahap Pertumbuhan Awal (Early-growth stage)

Tahapan awal pertumbuhan merupakan tahapan dimana wirausaha mulai tumbuh dan berkembang. Pada tahapan ini, usaha sudah mulai berjalan dengan baik, sehingga perlu dilakukan langkah-langkah pengembangan usaha. Namun untuk dapat melakukan pengembangan usaha, wirausaha pemula seringkali dihadapkan pada keterbatasan modal dan teknologi untuk pengembangannya. Pola-pola pendampingan dan pengembangan promosi sangat diperlukan dalam tahapan ini, sehingga wirausahawan dapat melakukan pengembangan usahanya. Pengembangan usaha dilakukan dengan peningkatan produksi maupun perluasan pasar.

4. Tahap Pertumbuhan Lanjutan (Later-growth stage)

Tahap pertumbuhan lanjutan merupakan tahapan dimana wirausahawan sudah cukup matang dan mampu mengelola usahanya dengan baik. Pada tahapan ini biasanya ditandai dengan pengembangan diversifikasi usaha, melebarkan wilayah dan jaringan pemasaran serta melakukan inovasi-inovasi produk baru. Pada tahapan pertumbuhan lanjutan ini, wirausaha akan dihadapkan pada persaingan yang semakin kompetitif. Untuk itu perlu dilakukan pengembangan kerjasama ataupun kemitraan untuk memperbesar usahanya.

Pengembangan kewirausahaan yang terarah dan terpadu tidak hanya menjadi tanggungjawab Pemerintah saja, tetapi juga harus melibatkan pemangku kepentingan yang lain. Pengembangan kewirausahaan paling tidak harus didukung oleh empat pilar utama yaitu Pemerintah, Perguruan Tinggi, dunia usaha (swasta) dan masyarakat. Keempat pilar utama tersebut harus saling bekerjasama dan saling bersinergi dalam mengembangkan kewirausahaan pemuda. 


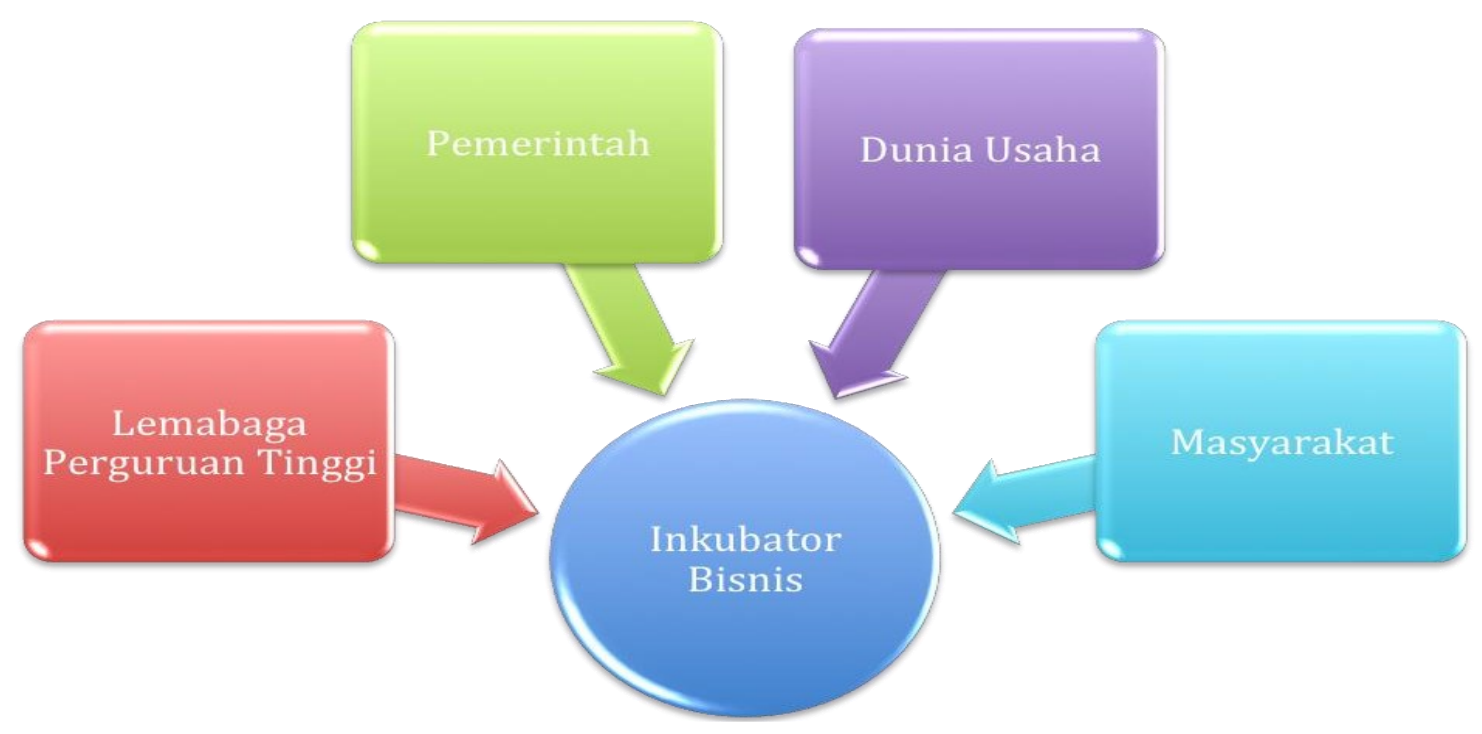

Gambar 2: Pola Pengemabangan Kewirausahaan melalui Inkubator Bisnis

Inkubator bisnis merupakan lembaga bisnis yang bergerak dalam bidang penyediaan fasilitas dan pengembangan usaha, baik manajemen maupun teknologi bagi wirausahawan untuk dapat mengembangkan usahanya dan atau pengembangan produk baru agar dapat berkembang menjadi wirausaha yang tangguh dan atau produk baru yang memiliki daya saing dalam jangka waktu tertentu. Pengembangan kewirausahaan dapat dilaksanakan dengan memanfaatkan inkubator bisnis, antara lain saat ini sudah berdiri di hampir setiap lembaga Perguruan Tinggi di Indonesia.

Pelatihan kewirausahaan dilaksanakan dengan menganut paradigma training ke arah learning, yaitu pelatihan yang berorientasi pembelajaran. Pelbagai metode yang digunakan dalam pelatihan meliputi:

1. Studi Kasus dan Diskusi Kelompok, mengajak peserta untuk mengkritisi kasus dan temuan dalam berbisnis, bertujuan untuk mempertajam analisa bisnis;

2. Curah Pendapat (Brainstroming), Proses kreatif untuk menghasilkan ide-ide yang berkaitan dengan pengalaman dan wawasan berbisnis;

3. Sumbang Saran, proses berbagi pengalaman antara peserta sebagai sumber pembelajaran dan motivasi dalam berbisnis;

4. Bermain Peran \& Game Simulasi Bisnis, simulasi bisnis yang akan mengulas tentang siklus bisnis, dinamika permintaan dan penawaran yang akan memberikan pembelajaran dan dapat diterapkan (aplikasi) dan diadaptasikan dalam bisnisnya;

5. Ceramah, sumber inspirasi dan wawasan dalam berbisnis mengenai pendekatan secara teoritis (tetapi dapat di implementasikan) dan contoh yang baik (best practice) dalam mengelola bisnis;

6. Latihan, bentuk pembelajaran aktif yang akan mendorong dan mengasah kemampuan 
peserta untuk mengembangkan diri terhadap pembelajaran yang telah mereka terima.

Pelatihan dasar-dasar akuntansi membahas mengenai konsep dasar, pengetahuan dan keterampilan akuntansi keuangan yang diperlukan dalam mengolah data penyajian laporan keuangan. melalui pelatihan ini, diharapkan dapat meningkatkan pemahaman atas konsep dasar, proses, dan penyusunan laporan keuangan, dapat menambah kemampuan dalam proses dan penyusunan laporan keuangan, serta membantu peserta memahami bisnis yang digeluti atau perusahaan dimana mereka bekerja. Materi-materi pelatihan oleh tim dosen pengabdian kepada masyarakat dapat disajikan berikut ini;

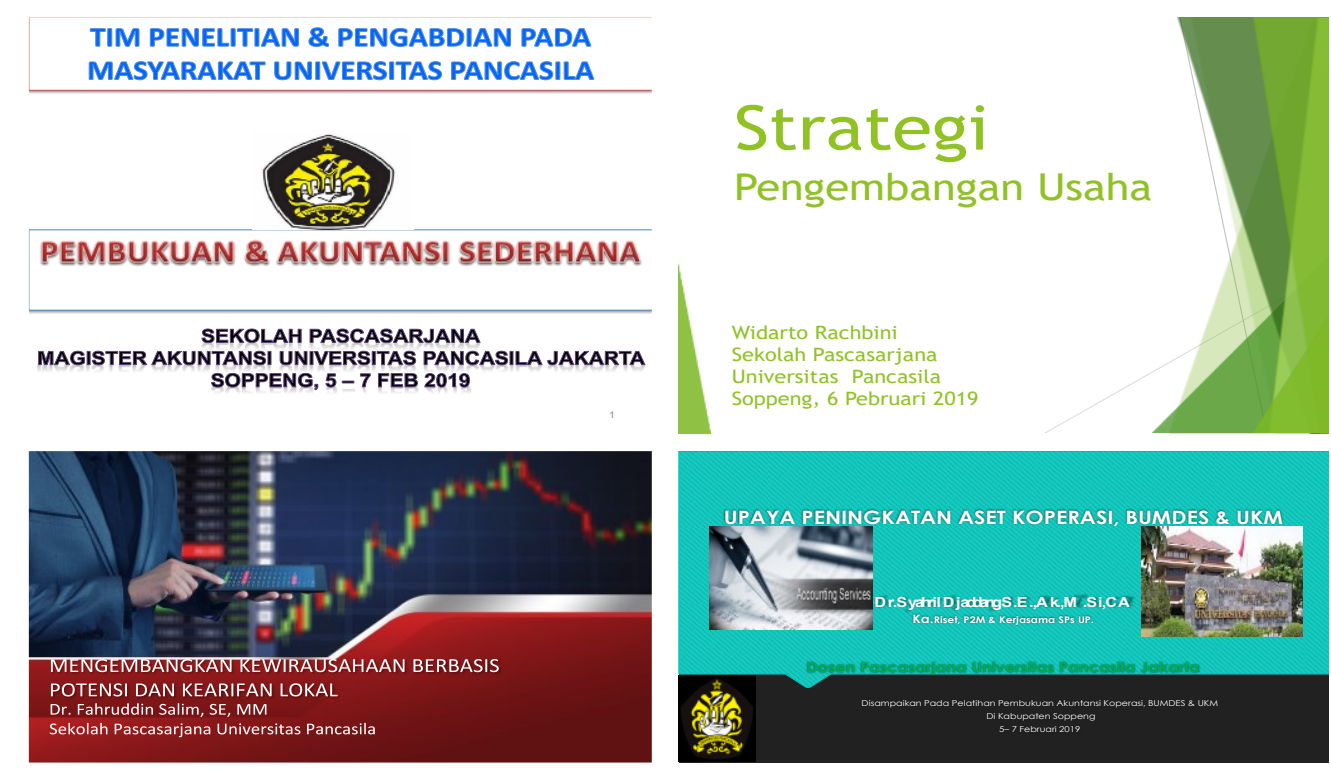

Gambar 3: Materi Pelatihan Dasar Kewirausahaan dan Akuntansi pada Kegiatan Pengabdian Masyarakat di Kabupaten Soppeng (5 - 7 Februari 2019)

Akuntansi seringkali dinyatakan sebagai bahasa perusahaan yang berguna untuk memberikan informasi yang berupa data-data keuangan perusahaan yang dapat digunakan guna pengambilan keputusan. Setiap perusahaan memerlukan dua macam informasi tentang perusahaannya yaitu informasi mengenai nilai perusahaan dan informasi tentang laba/rugi usaha. Kedua informasi tersebut berguna untuk:

- Mengetahui besarnya modal yang dimiliki perusahaan

- Mengetahui perkembangan ayau maju mundurnya perusahan

- Sebagai dasar untuk perhitunngan pajak

- Menjelaskan keadaan perusahaan sewaktu-waktu memerlukan kredit dari bank atau pihak lain

- Dasar untuk menentukan kebijakan yang akan ditempuh

- Menarik minat investor saham jika perusahaan berbentuk perseroan terbatas. 
Untuk memperoleh informasi-informasi tersebut diatas, pengusaha hendaknya mengadakan catatan yang teratur mengenai transaksi-transaksi yang dilakukan perusahaan yang dinyatakan dalam satuan uang.

Secara umum, UMKM di Indonesia berada pada tahap memulai usaha atau pada tahap pertumbuhan awal. Pelatihan ini bertujuan untuk memberikan pengetahuan dan kemampuan dasardasar pengelolaan usaha yang diperlukan bagi wirausaha pemula yang baru mulai usaha dan menjalankan rencana usaha yang telah disusun sebelumnya. Sasaran dari pelatihan penguatan usaha ini adalah pada wirausaha pemula yang berada pada tahap memulai usaha (the start-up stage) dan tahap pertumbuhan awal usaha (early-growth stage).

Pelatihan dasar kewirausahaan dan dasar-dasar akuntansi bagi pelaku ekonomi kreatif Koperasi, Bumdes, dan UMKM telah dilaksanakan melalui kerjasama antara Sekolah Pascasarjana Universitas Pancasila

1. Pelatihan Dasar Kewirausahaan

2. Pelatihan Dasar-dasar Akuntansi

3. Pengenalan Software Koperasi 3in1

4. Tutorial KSP - Angsuran Pinjaman Bebas

5. Tutorial KSP - Angsuran Pinjaman dengan Pembayaran Transfer Antar Bank

6. Tutorial KSP - Angsuran Pinjaman Kolektif Bank

7. Tutorial KSP - Angsuran Pinjaman Kolektif Tunai

8. Tutorial KSP - Angsuran Pinjaman Kolektif Tunai dengan Import Data Excell

9. Tutorial KSP - Angsuran Pinjaman Menggunakan KSP Android Collector

10. Tutorial KSP - Cara membuat dan Menggunakan Bilyet

11. Tutorial KSP - Cek Saldo Simapanan via SMS pada Software Koperasi 3in1

12. Tutorial KSP - Entry Pinjaman dengan Simpanan Wajib

13. Tutorial KSP - Entry Transaksi Kas-Bank pada Software Koperasi 3in1.

Kewirausahaan adalah kompetensi yang luas dan bermanfaat untuk mengambil tindakan yang bertujuan menggunakan sistem pendidikan untuk membekali peserta didik muda dengan pola pikir dan keterampilan wirausaha, termasuk rasa inisiatif, kreativitas, toleransi kegagalan, dll. Ini akan membantu kaum muda untuk mencapai tujuan yang mereka tetapkan untuk diri mereka sendiri. Memberikan pendidikan kewirausahaan di lembaga pendidikan tinggi adalah cara untuk meningkatkan jumlah pengusaha (European Comission, 2012). Pendidikan kewirausahaan bertujuan untuk mendorong start-up bisnis yang inovatif serta meningkatkan pola pikir kewirausahaan kaum muda untuk memungkinkan mereka menjadi lebih kreatif dan percaya diri dalam apa pun yang mereka lakukan dan untuk meningkatkan daya tarik mereka bagi pengusaha (Bialek-Jaworska and Gabryelczyk, 2015). 


\section{SIMPULAN}

Berdasarkan pembahasan diatas dapat disimpulkan beberapa hal sebagai berikut:

1. Indonesia memiliki budaya yang beragam, dari bahasa, adat istiadat, sistem nilai, untuk itu pengembangan ekonomi kreatif berbasis kearifan lokal merupakan salah satu comparative advantages dibandingkan negara lain yang tidak memiliki keragaman budaya.

2. Untuk menginisiasi kegiatan kewirausahaan di daerah diperlukan pelatihan kewirausahaan bagi pengurus dan anggota koperasi, Bumdes dan UMKM di daerah terutama di Kawasan Indonesia Timur.

3. Pelatihan mengenai dasar - dasar akuntansi sangat diperlukan untuk membina kegiatan kewirausahaan dalam melakukan pencatatan dan pelaporan keuangan usahanya sehingga pelaku usaha memperoleh akses premodalan baik dari bank maupun lembaga keuangan lainnya.

4. Lebih dari 96\% pelaku usaha ekonomi kreatif di Provinsi Sulawesi Selatan tidak memiliki badan hukum. Sebagai rekomendasi dan tindak lanjut diperlukan pembinaan dan pelatihan dibidang hukum dan legalitas usaha dalam rangka meningkatkan daya saing, tidak hanya ditingkat nasional, tetapi untuk memiliki daya saing secara internasional.

5. Inkubator bisnis di lembaga Perguruan Tinggi dioptimalkan perannya sebagai agen pembentuk wirausaha-wirausaha di daerah. Inkubator bisnis yang akan menjadi wadah pengembangan kewirausahaan masyarakt harus mendapatkan dukungan dari pelbagai pemangku kepentingan (pemerintah, dunia usaha, perguruan tinggi dan masyarakat) sesuai dengan perannya masing-masing.

\section{UCAPAN TERIMA KASIH}

Program Pengabdian Kepada Masyarakat ini dapat terselenggara berkat dukungan dari beberapa pihak, untuk itu kami menyampaikan terima kasih kepada:

1. Ketua Program Magister Akuntansi - Sekolah Pascasarjana Universitas Pancasila Jakarta.

2. Ketua lembaga Penelitian dan Pengabdian kepada Masyarakat Universitas Pancasila Jakarta.

3. Dinas Perdagangan, Perindustrian, Koperasi dan UKM Pemerintah Daerah Kabupaten Soppeng Sulawesi Selatan.

4. Semua pihak yang tidak dapat kami sebutkan satu per satu, yang telah mendukung pelaksanaan Kegiatan PKM ini sehingga dapat berjalan dengan baik dan lancar. 


\section{REFERENSI}

Abeng, Tanri. (2015). Badan Usaha Milik Rakyat (BUMR), Lembaga Pelaku Ekonomi dan Keuangan Inklusif, Jakarta. Elexmedia - Gramedia Group

Badan Ekonomi Kreatif (2019). OPUS: Ekonomi Kreatif Outlook 2019. Jakarta: Badan Ekonomi Kreatif Indonesia.

Badan Ekonomi Kreatif (2019). Infografis Sebaran Pelaku Ekonomi Kreatif. Jakarta: Badan Ekonomi Kreatif IndonesiaHowkins, John. (2013). The Creative Economy: How People Make Money From Ideas. England UK: Penguin Books.

Białek-Jaworska, A., \& Gabryelczyk, R. (2015). Stimulating entrepreneurship by teaching accounting: Concept and implementation. World Review of Entrepreneurship, Management and Sustainable Development, 11(2-3), 137-155.

Badan Pusat Statistik (2020). Kabupaten Soppeng Dalam Angka 2020, Badan Pusat Statistik Kabupaten Soppeng

European Commission (2012) New Skills and Jobs in Europe: Pathways Towards Full Employment, Directorate-General for Research and Innovation, Socio-economic Sciences and Humanities, Brussels.European

Hidayat, A. R. R. T., \& Asmara, A. Y. (2017). Creative industry in supporting economy growth in Indonesia: Perspective of regional innovation system. IOP Conference Series: Earth and Environmental Science, 70(1).

Satari, T. F. C. (2018). Strategy of Entrepreneurship \& Creative Economy Development through District Mapping in Bandung City. Journal of Visual Art and Design, 10(2), 93-100.

The Canadian Policy Research Group. (2013). The Creative Economy: Key Concepts and Literature Review Highlights, 1-48. 